\title{
PREDIKTOR PPREEKLAMPSI BERAT DITINJAU DARI KADAR ZINK RAMBUT, TEKANAN DARAH, PROTEIN URIN DAN BERAT BADAN
}

\author{
Ira Suryanis ${ }^{1}$, Dian Eka Nursyam², Diane Marlin ${ }^{3}$ \\ 1 Universitas Baiturrahmah \\ Email : ierha_soeryanis@ymail.com \\ 2Universitas Baiturrahmah \\ Email : dianeka_nursyam@yahoo.com \\ UUniversitas Adiwangsa Jambi \\ Email : dianemarlin@gmail.com
}

\begin{abstract}
Background Preeclampsia is a major complication in pregnancy and a major cause of maternal and fetal morbidity and mortality. The World Health Organization (WHO) reports $16 \%$ of deaths caused by preeclampsia in developing countries (Cunningham, 2014). The maternal mortality rate caused by hypertension, PE and eclampsia in West Sumatra is around $44.8 \%$ and continues to increase. During pregnancy there will be changes in maternal metabolism, these changes are needed for fetal development. The inadequacy of macronutrients and micronutrients can interfere with pregnancy and poor pregnancy outcomes (Maria T et al, 2014; Kanagal DV et al, 2014).

Purpose The purpose of this study was to determine the factors that can be used as predictors of the occurrence of severe preeclampsia in pregnant women with mild preeclampsia at gestational age $\geq 34$ weeks (PEAL), the variables studied were Hair Zinc, Blood Pressure, Body Weight, Protein and the measured twice at the time of the study

Method This study uses a cohort design, the study was conducted in health services in the Independent Practice Midwife and community health center in Padang City. The sample of this study was pregnant women who came to Padang city health services followed until delivery and performed two checks with inclusion criteria: gestational age $\geq 34$ weeks, single fetus, blood pressure $\geq 140 / 90$ and proteinuria $(+1)$ on the dipstick test

Result In table 1.1 it can be seen that the mean Hair Zinc level in preeclampsia pregnant women is $210.317 \pm 66.7 \mathrm{ng} / \mathrm{ml}$. The mean maternal body weight was $1.7 \pm 0.78$ and the mean Protein 1 score was $1.00 \pm$ 0.00 , the Systolic mean was $131 \pm 3.05$ and the Diastole was $90.0 \pm 0.00$.

Conclusion There is a correlation between urine protein, body weight, diastole blood pressure on body on late onset preeclampsia

Suggestion With the known predictors of preeclampsia that have a relationship such as urine protein, body weight and blood pressure with the occurrence of preeclampsia, it is expected that health workers can use these variables as early detection and markers in the case of preeclampsia
\end{abstract}

Keywords: Zinc, Blood Pressure, Protein, Weight, Late Onset Preeclampsia

\section{ABSTRAK}

Latar Belakang Preeklampsia adalah komplikasi utama dalam kehamilan dan merupakan penyebab utama morbiditas dan mortalitas ibu dan janin. Organisasi Kesehatan Dunia (WHO) melaporkan 16\% kematian yang disebabkan oleh preeklampsia di negara-negara berkembang (Cunningham, 2014). Angka kematian ibu yang disebabkan oleh hipertensi, PE dan eklamsi di Sumatera Barat yaitu sekitar $44,8 \%$ dan terus mengalami peningkatan. Selama kehamilan akan ada perubahan metabolisme ibu, perubahan ini diperlukan untuk perkembangan janin. Ketidakcukupan makronutrien dan mikronutrien dapat mengganggu kehamilan dan hasil kehamilan yang buruk (Maria T et al, 2014; Kanagal DV et al, 2014).

Tujuan dari penelitian ini adalah untuk mengetahui faktor-faktor yang dapat digunakan sebagai prediktor terjadinya preeklamsia berat pada wanita hamil dengan preeklamsia ringan pada usia kehamilan $\geq 34$ minggu (PEAL), variabel yang diteliti adalah Zink Rambut, Tekanan Darah, Berat Badan , Protein dan diukur dua kali pada saat penelitian

Metode Penelitian ini menggunakan desain kohort, penelitian dilakukan di layanan kesehatan di Bidan Praktek Mandiri dan pusat kesehatan masyarakat di Kota Padang. Sampel penelitian ini adalah wanita hamil 
yang datang ke layanan kesehatan kota Padang diikuti sampai melahirkan dan melakukan dua pemeriksaan dengan kriteria inklusi: usia kehamilan $\geq 34$ minggu, janin tunggal, tekanan darah $\geq 140 / 90$ dan proteinuria $(+1)$ pada tes dipstick

Hasil Dalam tabel 1.1 dapat dilihat bahwa tingkat Zinc Rambut rata-rata pada wanita hamil preeklampsia adalah $210,317 \pm 66,7 \mathrm{ng} / \mathrm{ml}$. Berat badan ibu rata-rata adalah 1,7 $\pm 0,78$ dan skor rata-rata Protein 1 adalah $1,00 \pm 0,00$, rata-rata Sistolik adalah $131 \pm 3,05$ dan Diastole adalah $90,0 \pm 0,00$

Kesimpulan Ada korelasi antara protein urin, berat badan, tekanan darah diastole pada tubuh pada preeklamsia berat

Saran Dengan diketahui prediktor preeklamsi yang memiliki hubungan yang seperti protein urin, berat badan dan tekanan darah dengan terjadinya preeklamsi, diharapkan kepada tenaga kesehatan dapat mengunakan variabel tersebut sebagai deteksi dini dan marker dalam kasus preeklamsi

Kata Kunci: Berat Badan, Tekanan Darah, Protein, PEAL, Zink

\section{PENDAHULUAN}

Preeklampsia (PE) adalah komplikasi utama dalam kehamilan dan penyebab utama morbiditas dan mortalitas ibu dan janin. Organisasi Kesehatan Dunia (WHO) melaporkan 16\% kematian yang disebabkan oleh preeklampsia di negara-negara berkembang. Angka preeklampsia antara $5-10 \%$ dari semua kehamilan (Cunningham, 2014)

Angka kematian ibu di negara berkembang yang disebabkan oleh PE adalah sekitar 5-10\% dan tingkat kematian janin sekitar $40 \%$. Angka kematian ibu yang disebabkan oleh hipertensi pada kehamilan (HDK) pada tahun 2010 di Indonesia lebih dari 30\% dan kejadian PE berkisar antara 310\% (Keman, et al., 2009).

Angka kematian ibu karena hipertensi, PE, dan eklampsia di Sumatera Barat adalah sekitar $44,8 \%$ dan terus meningkat di Rumah Sakit Pusat Dr. Angka ini meningkat setiap tahun, yaitu 193 kasus $(11,47 \%)$ dari 1.682 pengiriman selama 2012 , dan 206 kasus $(12,02 \%)$ dari 1.714 pengiriman pada 2013 (Rekam medis, 2012; rekam medis, 2013).

Preeklampsia masih merupakan penyakit teoritis. Berbagai penelitian belum dapat menembus penyebab pastinya dengan jelas. Teori yang banyak dipegang adalah: (1) teori kelainan vaskularisasi plasenta; (2) teori iskemia plasenta, radikal bebas dan disfungsi endotel; (3) teori intoleransi imunologis antara ibu dan janin; (4) teori adaptasi kardiovaskular; (5) teori kekurangan gizi; (6) teori inflamasi (Keman, et al., 2009; Steegers, et al., 2010).

Analisis faktor risiko preeklampsia diperlukan untuk mengurangi efek buruk preeklampsia. Teori definisi gizi adalah salah satu teori yang diadopsi dan selama kehamilan akan ada perubahan metabolisme ibu. Perubahan ini diperlukan untuk perkembangan janin. Makronutrien dan mikronutrien yang tidak memadai dapat mengganggu kehamilan dan hasil kehamilan yang buruk. Zat gizi mikro seperti vitamin $C$ dan $E$, tembaga, magnesium, selenium, dan zink adalah antioksidan yang sangat penting dalam setiap tahap kehamilan untuk berfungsi sebagai kofaktor enzim. Superoksida dismutase adalah enzim antioksidan yang mengandung unsur zink dan tembaga. Berbagai penelitian telah membuktikan salah satu faktor penyebab preeklampsia adalah stres oksidatif, zink sebagai antioksidan diperlukan untuk berfungsinya berbagai enzim dan faktor transkripsi (Maria T et al, 2014; Kanagal DV et al, 2014).

Hal yang berbeda dalam penelitian ini adalah mengetahui hubungan antara konsentrasi zink serum, tekanan darah, protein urin, berat badan dan keparahan preeklampsia. Dalam penelitian ini prediktor seperti kadar zink rambut, tekanan darah, protein urin, berat badan wanita hamil yang didiagnosis dengan Preeklampsia Onset Akhir akan terlihat dua kali selama kehamilan untuk melihat seberapa jauh perubahan dalam indikator ini dapat memprediksi kasus preeklamsia berat. Beberapa penelitian di Iran dan negara-negara lain merupakan prediktor preeklamsia berat dan hanya sedikit yang meneliti konsentrasi serum zink pada rambut ibu dan tingkat keparahan preeklampsia (Bahadoran P et al, 2010).

Tujuan dari penelitian untuk menentukan perubahan kadar zink, tekanan darah, berat badan, protein dan secara bertahap pada ibu yang terdiagnosa preeklamsi dan sampel diikuti sampai 2 minggu, yang dapat digunakan sebagai prediktor preeklamsia berat.

Dengan diketahui perubahan Tekanan Darah, Berat Badan, Protein dan Zink pada preeklamsia ringan, hasil penelitian ini dapat digunakan sebagai prediktor preeklamsia berat dan dapat memprediksi terjadinya preeklampsia pada wanita hamil. 


\section{METODE PENELITIAN}

Penelitian ini menggunakan desain kohort, penelitian dilakukan di layanan kesehatan di Bidan Praktek Mandiri dan pusat kesehatan masyarakat di Kota Padang. Sampel penelitian ini adalah wanita hamil yang datang ke layanan kesehatan kota Padang diikuti sampai melahirkan dan melakukan dua pemeriksaan dengan kriteria inklusi: usia kehamilan $\geq 34$ minggu, janin tunggal, tekanan darah $\geq 140 / 90$ dan proteinuria (+1) pada tes dipstick. Pemeriksaan kadar zink rambut pada rambut dilakukan di Laboratorium Kesehatan Daerah. Total sampel 30 ibu hamil dengan preeklamsia ringan. Pengujian hipotesis untuk digunakan dalam analisis bivariat menggunakan analisis univariat dan multivariate.

\section{HASIL DAN PEMBAHASAN}

Analisis univariat dilakukan untuk menentukan distribusi variabel kadar zink pada rambut, berat badan, protein urin, sistol tekanan darah dan diastole pada Preeklampsia dapat dilihat pada tabel 1 di bawah ini yang berisi mean dan standar deviasi masing-masing variable

Tabel 1 Rata rata Kadar zink, berat badan, protein urin, tekanan darah sistolik dan diastole pada preeklampsia.

\begin{tabular}{lcc}
\hline \multicolumn{1}{c}{ Variable } & $\mathrm{N}$ & Rata2 \pm SD \\
\hline Kadar zink 1 & 30 & $210,317 \pm 66,7$ \\
Kadar zink 2 & 30 & $185,713 \pm 54,9$ \\
Berat Badan 1 & 30 & $1,7 \pm 0,78$ \\
Berat Badan 2 & 30 & $1,8 \pm 0,06$ \\
Protein Urin 1 & 30 & $1,00 \pm 0,00$ \\
Protein Urin 2 & 30 & $1,53 \pm 0,73$ \\
Tekanan Darah Sistole 1 & 30 & $131 \pm 3,05$ \\
Tekanan Darah Sistole 2 & 30 & $153 \pm 28,0$ \\
Tekanan Darah Diastol 1 & 30 & $90,0 \pm 0,00$ \\
Tekanan Darah Diastol 2 & 30 & $102,6 \pm 16,38$ \\
\hline SD
\end{tabular}

SD $=$ Standar Deviasi

Pada tabel 1 dapat dilihat bahwa kadar zink rambut pada wanita hamil preeklampsia adalah $210,317 \pm 66,7 \mathrm{ng} / \mathrm{ml}$. Rata rata Berat badan ibu adalah $1,7 \pm 0,78$ dan Rata-rata Protein pada pemeriksaan pertama adalah $1,00 \pm 0,00$, Rata-rata tekanan darah Sistolik adalah $131 \pm 3,05$ dan Rata rata tekanan darah Diastole adalah 90,0 $\pm 0,00$.

Penelitian ini menggunakan uji korelasi Pearson untuk menentukan korelasi antara kadar zink rambut, protein urin, berat badan, tekanan darah diastolik dan preeklampsia. Korelasi kedua variabel ini dapat dilihat pada tabel 2 berikut ini.
Tabel 2 Korelasi kadar zink rambut, protein urin, berat badan, tekanan darah diastole pada preeklampsia

\begin{tabular}{llc}
\hline \multicolumn{1}{c}{ Variabel } & Preeklamsi \\
\hline Zinc Levels & $r=-, 062$ \\
Urine Protein & $p=0,743$ \\
& $r=0,758$ \\
body weight & $p=0,000$ \\
& $r=0,435$ \\
Tekanan darah diastol & $p=0,016$ \\
& $r=0,824$ \\
& $p=0,000$
\end{tabular}

* Uji Korelasi Pearson

Tabel 2 menunjukkan bahwa tidak ada korelasi antara kadar zink rambut dengan preeklamsia awitan lambat, dengan $p=0,743$ dan $r$ $=-0,62$, berdasarkan uji statistik kekuatan korelasi sangat lemah. Pada protein urin terdapat korelasi yang signifikan dengan nilai $p 000$ dan $r$ 0,758, dengan kekuatan korelasinya sangat kuat. Sementara itu untuk variable berat badan ada juga korelasi yang signifikan dengan nilai $p$ 0,016 dan kekuatan korelasi 0,435 , yang berarti kekuatan korelasi sedang. Dan perubahan tekanan diastole memiliki korelasi yang sangat kuat pada preeklampsi awitan lambat dengan nilai $r=0,824$, yang berarti nilai korelasinya sangat kuat.

Pada penelitian ini ditemukan tidak ada korelasi antara kadar zink rambut dengan preeklamsi awitan lambat, penyerapan kadar zink dapat dihambat oleh kadar zat besi dan juga dipengaruhi oleh paritas ibu. (Shriva, 2015). Pada penelitian ini tidak mengukur kadar zat besi ibu dan lebih dari separuh 21 dari 30 responden (70 \%) ibu memiliki paritas lebih dari 1 (multipara)

Ada beberapa faktor yang dapat mempengaruhi penyerapan dan ekskresi zink, antara lain, asupan yang tidak memadai, penyakit menular, kondisi fisiologis, peningkatan kebutuhan, ekskresi berlebihan dan interaksi antara zink dengan nutrisi dan non-nutrisi. Zink yang terkandung dalam sumber makanan nabati memiliki bioavailabilitas yang lebih rendah dibandingkan dengan makanan hewani karena tanaman mengandung berbagai senyawa yang dapat menghambat metabolisme zink dalam tubuh seperti fitat, polifenol, tanin dan serat. Selain asupan zink, asupan protein merupakan aspek penting yang memiliki pengaruh pada penyerapan zink (Riskesdas, 2008)

Asupan zat gizi perancu zink yang memiliki hubungan dengan serum zink. Tembaga adalah agen zink kompetitif dalam memperebutkan pengangkut dan ligan. Asupan tembaga yang 
berlebihan dapat mengganggu pengambilan ikatan zink oleh metalothionin dalam enterosit. Metalotionin memiliki afinitas yang lebih besar untuk tembaga daripada zink. (Lonnerdal B, 2007)

Pada penelitian ini variable berat badan memiliki korelasi yang signifikan dengan preeklamsi awitan lambat dengan nilai $p$ 0,016 dan kekuatan korelasi 0,435 , yang berarti kekuatan korelasi sedang Secara teori, kelebihan berat badan sebelum kehamilan meningkatkan risiko Preeklasmi. Ini disebabkan oleh peningkatan trigliserida serum dan kadar lipoprotein yang rendah pada wanita gemuk. Profil lipid seperti ini menginduksi stres oksidatif yang disebabkan oleh iskemia, mekanisme reperfusi dan aktivasi neutrofil yang menghasilkan disfungsi sel endotel. Selain itu menyebabkan atherothrombosis dan menginduksi agregasi trombosit yang pada gilirannya menyebabkan koagulopati yang merupakan karakteristik dari PE (Luealon, 2010).

Penelitian Kusika (2014) melaporkan bahwa tidak ada hubungan signifikan yang ditemukan antara kelompok indeks massa tubuh (BMI) dan kejadian Preeklamsi/ Eklamsi. Namun, penelitian Bodnar et al dalam Kusika (2014) menyatakan bahwa ada peningkatan risiko PE berlipat dua pada BMI 26 dan tiga kali lipat pada BMI> 30 dibandingkan dengan normal.

Hasil penelitian Moehlecke (2016), menemukan bahwa kenaikan berat badan di bawah $5 \mathrm{~kg}$ untuk kelompok obesitas dapat mengurangi risiko preeklampsia tanpa memberikan efek samping pada skor Apgar.

Dari dua hasil penelitian ini ditemukan bahwa penambahan berat badan lebih dari $5 \mathrm{~kg}$ pada kelompok obesitas, sehingga dapat disimpulkan bahwa salah satu faktor yang mempengaruhi proklamasi adalah penambahan berat badan.

\section{KESIMPULAN}

Kadar zinc rata-rata pada wanita hamil preeklampsia adalah 210,317 $\pm 66,7 \mathrm{ng} / \mathrm{ml}$. Berat badan ibu rata-rata adalah 1,7 $\pm 0,78$ dan skor ratarata Protein 1 adalah $1,00 \pm 0,00$, rata-rata Sistolik adalah $131 \pm 3,05$ dan Diastole adalah 90,0 \pm 0,00 (Tabel 1)

Tidak ada korelasi antara kadar zink rambut pada preeklamsia awitan lambat, dengan $\mathrm{p}$ $=0,743$ dan $r=-0,62$, berdasarkan uji statistik kekuatan korelasi sangat lemah. Pada protein urin terdapat korelasi yang signifikan dengan nilai $p 000$ dan $r \quad 0,758$, dengan kekuatan korelasinya sangat kuat. Sementara itu pada variabel berat badan ada juga korelasi yang signifikan dengan nilai $p$ 0,016 dan kekuatan korelasi 0,435, yang berarti kekuatan korelasi sedang. Dan perubahan tekanan diastole memiliki korelasi yang sangat kuat pada preeklampsi awitan lambat dengan nilai $r=0,824$, yang berarti nilai korelasinya sangat kuat. Ada korelasi antara protein urin, berat badan, tekanan darah diastole pada preeklamsia. (Tabel 2)

\section{SARAN}

Dengan diketahui prediktor preeklamsi yang memiliki hubungan yang seperti protein urin, berat badan dan tekanan darah dengan terjadinya preeklamsi, diharapkan kepada tenaga kesehatan dapat mengunakan variabel tersebut sebagai deteksi dini dan marker dalam kasus preeklamsi

\section{DAFTAR PUSTAKA}

Bahadoran Parvin, Manoush Zendehdel, Ahmad Movahedian, and Roshanak Hasan Zahraee. (2010). The Relationship between serum Zinc Level and Preeclampsia. Iran J Nurs Midwifery Research. Summer; 15(3): 120-124.

Benomar $Y$ et al, 2013. Central Resistin Overexposure Induces Insulin Resistance Through Toll-Like Receptor 4.Vol 62(102 14). American Diabetes Association

Cunningham FG et al. 2014. Chapter 24 Pregnancy Hypertension dalam: Williams Obstetrics 24rd. New York: The McGraw Hill Companies.

Gabriel, J. F. 2011. Fisika Lingkungan. Jakarta: Penerbit Hiprokrates

Guyton, Arthur C dkk. 2008. Buku Ajar Fisiologi Kedokteran Edisi 11. Jakarta: EGC.

Huppertz B, 2008. Placental Origins of Preeclampsia: Challenging The Current Hypothesis. Hypertension. 51, 970 - 75

Kanagal DV, Rajesh A, Rao K, Shetty H, Shetty PK, Ullal H (2014). Zinc And Copper Levels In Preeclampsia: A Study From Coastal South India. Int J Reprod Contracept Obstet Gynecol 2014;3:370-3. DOI: 10.5455/2320-1770.jircog20140617

Keman, $\mathrm{K}$ et al. 2009. Perbedaan Ekspresi p53, Bcl2 dan Indeks Apoptosis Trofoblas Pada Preeklampsia/Eklampsia dan Kehamilan Normal. Majalah Obstetri Ginekologi Indonesia

Lonnerdal B. 2007. Dietary Factors Influencing Zinc Absorption. The Journal of Nutrition.130:1378S-83S.

Maria Thomas, Jenu dan P Shenoy, Revathi dan Bhat, Parvati dan Rao, Pragna (2014). 
Pathophysiology Of Preeclampsia and Possinle Role Of Zinc In Its Genesis. DOl: 10.10.2174/ 157340481001141030092250

Prawirohardjo, S. 2009. IImu Kebidanan. Jakarta: Yayasan Bina Pustaka Sarwono Prawirohardjo

Rekam Medik, 2012. Bagian Obstetri dan Ginekologi RSUP. Dr. M. Djamil Padang periode 1 Januari sampai 31 Desember 2012.

Rekam Medik, 2013. Bagian Obstetri dan Ginekologi RSUP. Dr. M. Djamil Padang periode 1 Januari sampai 31 Desember 2013.

Shriva, Stava Jyot Sna1, agrawal amit2, aravind Kumar. 2015. Study of Serum Zinc in Low Birth Weight Neonates and Its Relation with Maternal Zinc. Jurnal of Clinical and Diagnostic Research. Jan, Vol-9(1): SC01SC03

Steegers, E A et al. 2010. Pre-eclampsia. The Lancet, 376, pp. 631-44. 